\title{
Letter: Sacrum agenesis and scimitar sacrum in Currarino syndrome
}

\author{
Naci Balak ${ }^{1}$ \\ Received: 1 September 2020 / Accepted: 7 September 2020 / Published online: 11 September 2020 \\ (C) Springer-Verlag GmbH Germany, part of Springer Nature 2020
}

\section{Dear Editor:}

The article entitled "Sacrum agenesis and scimitar sacrum in Currarino syndrome" by Corrêa et al [1] and published in Child's Nervous System (2020) 36:1337-1338 presents a rare and interesting case. Their clinical findings will undoubtedly benefit physicians, since early diagnosis and treatment are essential to avoid morbidity and mortality in patients with Currarino syndrome [2]. However, information on the surgical treatment of the patient and its discussion is missing. As the authors stated, the mortality rate of patients who do not undergo surgery is $30 \%$, due to complications such as pelvic obstruction, rectal erosion, and enterothecal fistula [1]. Rupture of an anterior sacral meningocele (ASM) can occur spontaneously and may result in meningitis or spinal abscess [2].

Although some authors maintain that surgery should not be performed in asymptomatic patients, the treatment goal of ASM in Currarino syndrome is obliteration of the communication between the spinal subarachnoid space and the meningocele. A posterior approach with lumbar and/or sacral laminectomy and transdural ligation of the meningocele neck provides adequate treatment $[2,3]$. Sectioning the filum terminale is also done if there is additional tethered spinal cord syndrome. A resection of the ASM is usually not necessary because the residual meningocele sac will be absorbed gradually over time $[2,3]$. If the neck of the meningocele is too large to ligate, then an anterior abdominal approach can be used. It should be kept in mind that the meningocele can be tightly adhered to the posterior wall of the rectum and an attempt to resect the meningocele may injure the rectum. An alternative surgical intervention reported is endoscopic approach [4]. Treatment of a solid presacral mass, such as of a teratoma, is more difficult than treatment for ASM and should be tailored to the individual patient $[2,3,5]$. Anorectal malformations, another component of Currarino syndrome, are treated by pediatric surgeons.

\section{Compliance with ethical standards}

Conflict of interest The author has no personal, financial, or institutional interest in any of the drugs, materials, or devices described in this article.

\section{References}

1. Correa DG, Daltro PA (2020) Sacrum agenesis and scimitar sacrum in Currarino syndrome. Childs Nerv Syst 36:1337-1338

2. Isik N, Elmaci I, Gokben B, Balak N, Tosyali N (2010) Currarino triad: surgical management and follow-up results of four [correction of three] cases. Pediatr Neurosurg 46:110-119

3. Isik N, Balak N, Kircelli A, Goynumer G, Elmaci I (2008) The shrinking of an anterior sacral meningocele in time following transdural ligation of its neck in a case of the Currarino triad. Turk Neurosurg 18:254-258

4. Clatterbuck RE, Jackman SV, Kavoussi LR, Long DM (2000) Laparoscopic treatment of an anterior sacral meningocele. Case illustration. J Neurosurg 92:246

5. Isik N, Balak N, Silav G, Elmaci I (2008) Pediatric intramedullary teratomas. Neuropediatrics 39:196-199

Publisher's note Springer Nature remains neutral with regard to jurisdictional claims in published maps and institutional affiliations.

Naci Balak

naci.balak@gmail.com; drnacibalak@yahoo.com

1 Department of Neurosurgery, Istanbul Medeniyet University, Göztepe Education and Research Hospital, Kadiköy, Istanbul, Turkey 